\title{
A Comparative Study between the Use of Honey and Sterile Nonviable Lyophillized Amniochorionic Membrane for the Treatment of Infected Wound in Type 3 Open Fractures
}

\author{
Charles A. Simanjuntak, H. Soelarto Reksoprodjo
}

\begin{abstract}
Abstrak
Telah dilakukan penelitian klinis terhadap luka 40 kasus patah tulang terbuka tingkat III, di bangsal orthopaedi RS Fatmawati dalam kurun waktu 10 bulan. Dua puluh kasus luka dirawat dengan mempergunakan madu murni dan 20 kasus lainnya dirawat dengan menggunakan selaput amniochorion kering steril yang diperoleh dari Pusat Penelitian Aplikasi Isotop dan Radiasi, Badan Tenaga Atom Nasional secara cuma-cuma. Dilakukan penelitian terhadap lama perawatan di rumah sakit, biaya dan respon luka terhadap kedua bahan diatas. Dari hasil penelitian didapat bahwa kedua bahan mempunyai efek yang sama baik. tidak terlihat perbedaan berınakna antara kedua bahan tersebut, kecuali madu murni lebih murah, aman mudah mencari dan menggunakannya selama perawatan.
\end{abstract}

\begin{abstract}
A clinical trial had been performed on 40 cases of the wound of open fracture type 3 in the orthopaedic ward of Fatmawati Hospital, Jakarta during 10 months. Twenty cases were treated by using pure honey on the wound, the other 20 cases were treated by using Sterile nonviable lyophillized amniochorionic membrane as biological dressing. These membranes were donated by The Centre for Application of Isotop and Radiation of National Atomic Energy Agency free of charge. This study was to compare the duration of stay in hospital, the expenses and the response of healing using honey and sterile nonviable lyophillized amniochorionic membrane as biological dressing. Both had the same good effect on infected wounds type 3 open fracture treatment. There was no statistically significant difference beetwen these two groups except that the use of honey as biological dressing is inexpensive, save, easy to get and to apply.
\end{abstract}

Keyword: Wound treatment, Sterile nonviable lyophillized amniochorionic membrane, Honey

Infected wounds in open fracture usually produce a lot of problems in the healing process of the fracture. It can cause osteomyelitis and also non-union or pseudoarthrosis. As a result, the patient has to stay longer in the hospital for treatment, and cost will be higher. ${ }^{1,2,3,4,5}$ Many methods has been tried to solve this problem, including the duration of the use of antibiotics, prophylactic as well as therapeutic, varying from one week until months depending on the type of microorganism as has been recommended by the team of nosochomial study of the hospital. ${ }^{6,7}$

During the second World War, Trueta, used a method for the treatment of open fractures, using a circular cast and keeping it until the fracture healed, although the cast gave an unpleasant odour. At that time the wound had been granulated or healed spontaneously. 8
In the literature, honey or sterile nonviable lyophillized amniochorionic membrane is used as a biological dressing to promote wound healing. $4,5,9,10,11$

A prospective study was carried out to study the benefits of using these materials in the treatment of wounds of type 3 open fracture.

The purpose of this study was to compare the duration of stay inhospital, the expenses and the response of healing using honey and nonviable lyophillized amniochorionic membrane as biological dressing.

\section{MATERIALS AND METHODS}

Since March 1, 1992 until December 31, 1992, forty patients (thirty seven males and three females) with type 3 open fractures who were hospitalized in the Orthopaedic Ward of Fatmawati Hospital, Jakarta (Table 1) were included in this study and divided into 
two groups. The first group consists of twenty patients using honey and the second group consists of twenty patients using sterile nonviable lyophillized amniochorionic membrane in the treatment of their wound.

Table 1. Sex distribution

\begin{tabular}{l|c|c|c|c}
\hline \multirow{2}{*}{ Sex } & \multicolumn{2}{|c|}{ Group } & \multirow{2}{*}{ Total } & $\%$ \\
\cline { 2 - 3 } & I & II & & \\
\hline Male & 18 & 19 & 37 & 92,5 \\
Fernale & 2 & 1 & 3 & 7,5 \\
\hline Total & 20 & 20 & 40 & 100,0 \\
\hline
\end{tabular}

Group I : cases using Honey

Group II : cases using Sterile nonviable amniochorionic membrane

The age ranged from $12-60$ years. The diameter of the wound were larger than 5 centimeters. Patients with a history of any disease that alters wound healing such as diabetic, leprosy, vascular disease, etc, were excluded from the study group. Also in severe brain concussion or psychosis. Patients who refused to continue the treatment for any reason will also be excluded from the study.

All patients will be treated in the usual procedure of treatment for type 3 open fracture. A swab from the wound was taken for microorganism study before debridement was performed in the operating theatre. Every odd number case was grouped into Group I using Honey as biological dressing which was changed every six hour. Every even number case was grouped into Group II using Sterile nonviable lyophillized amniochorionic membrane as biological dressing and will be changed every two days. No antibiotics were given to the patients, neither topical, oral nor parenteral. With the usual procedure, antibiotics were given during and until three days after operation.

The honey that was used was bought from any market; the purity of the honey can be tested by: 1 puting some of the honey on a disk and exposed it in the room. Pure honey will not attract or surrounded by ants. 2 The solubility in water and alcohol: pure honey will not solve in water nor alcohol.

The sterile nonviable lyophillized amniochorionic membrane was prepared and given free of charge by The Centre for Application of Isotops and Radiation of the National Atomic Energy Agency (Pusat Penelitian Aplikasi Isotop dan Radiasi, Badan Tenaga Atom Nasional - PAIR,BATAN). The membrane was attached to one side of a gauze measuring ten by ten centimeters and packed in a sterile plastic package.

Recording was done every two weeks. Criterias that were recorded include: 1 type of microorganism, 2 suppuration, 3 diameter of the wound, 4 time of granulation tissue that appears, at the end of the study. If at the end of the study the diameter of the wound is more than $2,5 \mathrm{~cm}$, the presence of healty granulation tissue and haemoglobin level above $10 \mathrm{~g} / \mathrm{dl}$ is an indication for skin grafting.

Results were expressed as mean $\pm S D$. Differences in mean values between the two groups were evaluated by the unpaired t-test with $\mathrm{p}<0,01$ considered significant.

\section{RESULT}

The mean age in Group I was 28,9 years $\pm 10,7$, and in Group II 24,4 years \pm 8 , (Table 2 ). There was no significant difference $(p>0.05)$.

Table 2. Age Distribution

\begin{tabular}{l|c|c|c|c}
\hline \multirow{2}{*}{$\begin{array}{c}\text { Age } \\
\text { (years) }\end{array}$} & \multicolumn{2}{|c|}{ Group } & \multirow{2}{*}{ Total } & $\%$ \\
\cline { 2 - 3 } & I & II & & \\
\hline $12-20$ & 8 & 7 & 15 & 37,5 \\
$21-30$ & 4 & 9 & 13 & 32,5 \\
$31-40$ & 2 & 3 & 5 & 12,5 \\
$41-50$ & 5 & 1 & 6 & 15,0 \\
$>50$ & 1 & 0 & 1 & 2,5 \\
\hline Total & 20 & 20 & 40 & 100,0 \\
Mean & 28,9 & 24,4 & - & - \\
SD & 10,7 & 8.0 & - & - \\
\hline
\end{tabular}

Group I : cases using Honey

Group II : cases using Sterile nonviable amniochorionic membrane

The diameter of the wounds ranged from 5 to 20 $\mathrm{cm}$ (Table 3) with an avarage of $5-10 \mathrm{~cm}(67,5 \%)$. The mean diameter in Group I was $10,5 \mathrm{~cm} \pm 4,83 \mathrm{~cm}$, while in Group II $8,75 \pm 2,68 \mathrm{~cm}$; there was no significant difference $(p>0.05)$. 
Table 3. Wound Diameter Distribution

\begin{tabular}{l|c|r|c|c}
\hline \multirow{2}{*}{$\begin{array}{c}\text { Wound } \\
\text { Diameter } \\
(\mathrm{cm})\end{array}$} & \multicolumn{2}{|c|}{ Group } & \multirow{2}{*}{ Total } & $\%$ \\
\cline { 2 - 3 } & $\mathrm{I}$ & $\Pi$ & & \\
\hline $5-10$ & 11 & 16 & 27 & 67,5 \\
$11-15$ & 6 & 3 & 9 & 22,5 \\
$16-20$ & 3 & 1 & 4 & 10,0 \\
$>20$ & 0 & 0 & 0 & 0,0 \\
\hline Total & 20 & 20 & 40 & 100,0 \\
Mean & 10,5 & 8,75 & - & - \\
SD & 4,83 & 2,68 & - & - \\
\hline
\end{tabular}

Group I : cases using Honey

Group II : cases using Sterile nonviable amniochorionic membrane

Duration of stay in a hospital for treatment of a wound ranged from twelve to thirty-eight days (Table 4). Mean of duration of stay (hospitalized) in Group I was 3,6 weeks ( 25 days) $\pm 1,28$ weeks ( 9 days), while in Group II 2,8 weeks ( 20 days) $\pm 0,87$ week ( 6 days); there was no significant difference $(p>0,01)$.

Table 4. Duration of Hospital Stay

\begin{tabular}{l|r|r|r|c}
\hline \multirow{2}{*}{$\begin{array}{c}\text { Length of } \\
\text { Stay } \\
\text { (weeks) }\end{array}$} & \multicolumn{2}{|c|}{ Group } & \multirow{2}{*}{ Total } & $\%$ \\
\cline { 2 - 3 } & I & II & & \\
\hline $0-2$ & 1 & 3 & 4 & 10,0 \\
$2-4$ & 13 & 16 & 29 & 72,5 \\
$4-6$ & 5 & 1 & 6 & 15,0 \\
$6-8$ & 1 & 0 & 1 & 2,5 \\
$>8$ & 0 & 0 & 1 & 0,0 \\
\hline Total & 20 & 20 & 40 & 100,0 \\
Mean & 3,6 & 2,8 & - & - \\
SD & 1,28 & 0,87 & - & - \\
\hline
\end{tabular}

Group I : cases using Honey

Group II : cases using Sterile nonviable amniochorionic membrane

The microorganism that had been isolated before treatment of these two groups were in thirty-three cases $(82,5 \%)$ Staphylococcus and the rest were Streptococcus. There was no Gram Negative staining nor other Gram positive staining microorganism other than Staphylococcus and Streptococcus isolated from the wound.

There were eleven cases of Group I and fifteen cases of Group II who did not need skin grafting due to the fact that the diameter of the wound after four weeks of treatment became less than $2,5 \mathrm{~cm}$ with minimal suppuration. Nine cases $(45 \%)$ of Group I and five cases (25\%) of Group II need skin grafting and the result was excellent (Table 5).

Table 5. Results of Skin Grafting

\begin{tabular}{c|c|c|c}
\hline \multirow{2}{*}{$\begin{array}{c}\text { Successful } \\
(\%)\end{array}$} & I & II & \multirow{2}{*}{ Total } \\
\cline { 2 - 3 } & 0 & 0 & 0 \\
\hline $0-24$ & 0 & 0 & 0 \\
$25-49$ & 0 & 0 & 0 \\
$50-75$ & 9 & 5 & 14 \\
$>75$ & 9 & 5 & 14 \\
\hline Total & & 5 & \\
\hline
\end{tabular}

Group I : cases using Honey

Group II : cases using Sterile nonviable amniochorionic membrane

At the end of the study, the cost for each patient was calculated. Group I needed 69 bottles $(650 \mathrm{ml} / \mathrm{bot}-$ tle) of honey; each bottle costing Rp. 12.000,- The average need for one patient was 3,45 bottles (Rp. $41.400,-)$. Group II needed 138 pieces of Sterile nonviable lyophillized amniochorionic membrane or about seven pieces for each patient. These membrane was free of charge, donated by the Centre for Application of Isotops and Radiation of National Atomic Energy Agency, so we could not calculate the cost for each patient if they had to pay for the membrane preparation.

\section{DISCUSSION}

A prospective comparative study of patients with open fracture type 3 using honey or sterile nonviable lyophillized amniochorionic membrane as a biological dressing in treating their wounds has been carried out. Group I and II are comparable since variant were not statistically different.

This study showed that those two materials can promote wound healing. None of the patients became worse, although none of them received any type of antibiotic topically, orally nor parenterally.

The mean duration of hospitalization of Group I, $25 \pm 9$ days and group II $20 \pm 6$ days, was not significantly different $(p>0,01)$. Hanafiah, in their study of 17 cases using Sterile nonviable lyophillized amniochorionic membrane, found that the duration of hospitalization was 9 - 13 days (mean 11,67 days) but 
they did not mention the size of diameter of the wound. ${ }^{4}$ Risantoso reported of 30 cases using honey, the time of hospitalization was $2-4$ weeks to cure the wound. Seventeen of them were established sterile at the end of the study. The diameter of the wound was not mentioned either. ${ }^{5}$

Staphylococcus is the most common microorganism that had been isolated from the wound, as has been reported by record authors. $1,2,6,12,1314$ The bactericidal effect of Sterile nonviable lyophillized amniochorionic membrane had been reported and published. ${ }^{4,9,11}$ Wotton wrote that honey contains Inhibin which acts as antibacterial. These two materials, honey and sterile nonviable lyophillized amniochorionic membrane, have an effect to promote wound tissue granulation. ${ }^{4,10,14}$ All of the patients healed well although nine cases ( $45 \%$ ) of Group I and five cases (25\%) of Group II needed skin grafting with excellent result.

Patients of Group I only spent Rp. 41.400 (about US\$ 20) for the honey they used; if they needed oral antibiotics, first or second generation cephalospo-rin for about three weeks, the cost was approximately $\mathrm{Rp}$. 120.000 ,- (US\$ 60) or in severe cases where more potent antibiotics were needed such as quinolon, then they had to spend about Rp. 270.000 (US\$135) or they might need parenteral antibiotics which are 3 to 4 times more expensive than orals. In treating patients of Group I, the dressing was changed every six hours; because the hygroscophic effect of the honey that has the bactericidal effect decreases. Honey is easily available in the market. Sterile nonviable lyophillized amniochorionic membrane is given free of charge and supplied by the National Atomic Energy Agency. In the United Kingdom, Yorkshire Tissue Banking, each piece of $15 \times 10$ centimeters costs 8.2 pound sterling $\left(R_{p} 25.000\right)$. So if it is calcuted, each patient need $\mathrm{Rp}$ 175.000. More attention of the doctors and nurses is necessary in the treatment using sterile nonviable lyophillized amniochorionic membrane. In early phases, the patients of Group II were usually complaining of unpleasant odor from the wound dressing because the dressing was changed, usually, every two days.

\section{CONCLUSION}

The result of a comparative study in the treatment of infected wounds in type 3 open fractures using honey and sterile nonviable lyophillized amniochorionic membrane had been reported. The wound diameter were all more than five centimeters. This study was carried out on patients treated in the Orthopaedic Ward at Fatmawati Hospital Jakarta during a ten-months period from March to December 1992. Twenty cases using honey and the rest using sterile nonviable lyophillized amniochorionic membrane as biological dressing for wound treatment of type 3 open fracture gave excellent results.

The conclusion is that in both groups, the use of this biological dressing had the same and good effect in the treatment of infected wounds of type 3 open fractures. There were no statistically significant differences between these two groups, except that the use of honey as biological dressing is inexpensive, save, and easy to get and to apply.

\section{REFERENCES}

1. Gustillo RB, Anderson JT. Prevention of Infection in the Treatment of One Thousand and Twenty Five Open Fractures of Long Bones. JBJS 1976; 58A (4): 453 - 8.

2. Gustillo RB, Merkow RL, Templeman D. The Management of Open Fractures. JBJS 1990; 72A (2): 299 - 303.

3. Gustillo RB, Mendoza RM, William DN. Problems in the Management of Type III (Severe) Open Fractures: A New Classification of Type III Open Fractures. J Trauma 1984; $24(8): 742-6$.

4. Hanafiah D, Reksoprodjo S, Hilmy N. Clinical Studies on Application of Sterile Lyophillized Amniochorion Membrane on Open Wound: Symposium on Surgical Tissue Banking. 1989 In press.

5. Risantoso T, Reksoprodjo S. Aplikasi Madu pada Luka Patah Tulang Terbuka. Majalah Orthopaedi Indonesia 1992; $\mathrm{XX}(1): 52-60$.

6. Fitzgerald RH. Infection; In Orthopaedic Knowledge Update Home Study Syllabus. American Academic of Orthopaedic Surgeon 1987; 49 - 55 .

7. Lange RH, Bach AW, Hansen ST, Johansen KH. Open Tibial Fractures with Associated Vascular Injuries: Prognosis for Limb Salvage. J Trauma 1985; 25 (3): 203 - 8.

8. Djojosugito AM, Rushadi D, Reksoprodjo $S$. Treatment of Infected Unjon and Fracture by Papineau Methods. Maj. Orthop Indone 1979; V (2): 92 - 101.

9. Bartholdson L. Antibacterial Effect of Biological Dressing in the Treatment of Infected Wound. Scan J Plast 1977; 11 (1): $33-7$.

10. Efem SE. Clinical Observation on the Wound Healing Properties of Honey. British J Surg 1988; 75 (7): 679 - 81.

11. Egan TJ. Human Amniotic in Management of Chronic Ulcer of Lower Limb. A Clinical Pathology Study. Angiology 1983; 34 (3): 197 - 203.

12. Bower WH, Wilson FC, Greene WB. Antibiotic Prophylaxis in Experimental Bone Infection. JBJS 19.73; 55A (4): 795 - 807.

13. Fitzgerald RH, Thompson RL. Current Concepts Review: Cephalosporin Antibiotics in the Prevention and Treatment of Musculoskeletal Sepsis. JBJS 1983; 65A (8): 1201 - 5.

14. Patzakis MJ, Harvey JP, Ivler D. The Role of Antibiotics in the Management of Open Fractures. JBJS 1974; 65A (3): 532 -41 . 